\title{
Synthesis, Crystal Structure and Characterization of Cu2 (PO4) (OH)
}

\author{
R. Ayadi, M. Boujelbene* and T. Mhiri
}

1-Laboratory of the Physico-Chemistry of Solid States. LR11 ES51 of Sfax. Road of Soukra km 4. Sfax 3071. Tunisia.

Email:Rayda_ayadi@yahoo.fr

1- Laboratoire Physico-Chimie de l'Etat Solide LR11 ES51. Université de Sfax. Faculté des Sciences de Sfax. Route de Soukra Km 3.5. BP 802. Sfax 3071. Tunisia.

Email: m_boujelbene2010@yahoo.fr

1- Laboratoire Physico-Chimie de l'Etat Solide LR11 ES51. Université de Sfax. Faculté des Sciences de Sfax. Route de Soukra Km 3.5. BP 802. Sfax 3071. Tunisia

Email: taharmhiri@yahoo.fr

\section{Abstract}

This paper reports the hydrothermal synthesis and crystal structure refinement of cuivre phosphate hydroxide, $\mathrm{Cu}_{2}\left(\mathrm{PO}_{4}\right)$ $(\mathrm{OH})$, obtained at $453 \mathrm{~K}$.

Its structure consists of chains of edge-sharing, distorted $\left[\mathrm{CuO}_{4}(\mathrm{OH})_{2}\right]$ octahedral extending parallel to [001]. These chains are cross linked by isolated $\mathrm{PO}_{4}$ tetrahedra through corner-sharing, forming channels in which dimmers of edgesharing $\left[\mathrm{CuO}_{4}(\mathrm{OH})\right.$ ] trigonal bipyramids are located. The structure is stabilized by medium to weak $\mathrm{O}-\mathrm{H} \ldots \mathrm{O}$ hydrogen bonds. In contrast to the previous refinement single crystal X-ray and analysis of data from vibrational spectroscopy, all non $-\mathrm{H}$ atoms were refined with anisotropic displacement parameters and the $\mathrm{H}$ atom was located.

KEYWORDS: Inorganic compounds; X-ray diffraction; Infrared spectroscopy; Raman spectroscopy.

\section{Council for Innovative Research}

Peer Review Research Publishing System

\section{Journal: Journal of Advances in Chemistry}

\author{
Vol. 5, No. 2 \\ editor@cirworld.com \\ www.cirworld.com, member.cirworld.com
}




\section{Introduction}

The isostructural M'M" $\mathrm{PO}_{4} \cdot \mathrm{H}_{2} \mathrm{O}$ type compounds $\left(\mathrm{M}^{\prime}=\mathrm{K}^{+}, \mathrm{NH}_{4}^{+} ; \mathrm{M}^{\prime \prime}=\mathrm{Mg}^{2+}, \mathrm{Mn}^{2+}, \mathrm{Fe}^{2+}, \mathrm{Co}^{2+}, \mathrm{Ni}^{2+}\right)$ crystallize in the orthorhombic space group $P m n 2_{1}\left(\mathrm{C}_{2 \mathrm{v}}\right)$ with $\mathrm{Z}=2$ [1].

Crystal structure data from single monocristal x-ray measurements are available for $\mathrm{NH}_{4} \mathrm{M}^{\prime \prime} \mathrm{PO}_{4} . \mathrm{H}_{2} \mathrm{O}(\mathrm{M}$ " = Co, Ni) [2-4] and $\mathrm{K} \mathrm{Mg} \mathrm{PO}_{4} \mathrm{H}_{2} \mathrm{O}[5]$.

Olivenite, ideally $\mathrm{Cu}_{2}\left(\mathrm{AsO}_{4}\right)(\mathrm{OH})$, is a common secondary mineral of the oxidized zone of hycrothermal deposits. It crystallizes with monoclinic symmetry in space group $P 2_{1} / n$ with a pseudo-orthorhombic cell $\left(\beta=90^{\circ}\right)$. Several arsenates and phosphates belong to the olivenite miniral group, including adamite, $\mathrm{Zn}_{2}\left(\mathrm{AsO}_{4}\right)(\mathrm{OH})$ eveite, $\left.\mathrm{Mn}^{2+}{ }_{2}(\mathrm{AsO})\right)(\mathrm{OH})$, zincolibethenite, $\mathrm{Cu} \mathrm{Zn}\left(\mathrm{PO}_{4}\right)(\mathrm{OH})$ and zincolivenite $\mathrm{Cu} \mathrm{Zn}\left(\mathrm{AsO}_{4}\right)(\mathrm{OH})$. Interestingly, except olivenite, all other minerals in this group display orthorhombic symmetry and crystallize in space groupe Pnnm. The first approximate structure determination of olivenite was reported by heritsch[6] in space group Pnnm. Subsequent studies on olivenite, however, proposed various other space groups: $\mathrm{P} 2{ }_{1} 2_{1} 2_{1}$ [7], $\mathrm{P}$ nnm [8], and $\mathrm{P} \mathrm{n} 2{ }_{1} \mathrm{~m}$ [9].

Toman [10] proposed that olivenite has actually monoclinic symmetry, and that most of the crystals are twinned. Hawever, Toman[10] did not report any atomic displacement parameters or the position of the $\mathrm{H}$ atoms. To avoid the complication of interpreting X-ray diffraction intensity data due to twinning, Burns and Hawthorne [11] performed structure refinements of olivenite using the Rietveld method from powder X-ray diffraction data. By assuming a single isotropic displacement parameter for all $\mathrm{O}$ atoms and no Hatom position, thayattempted refinement both in space group $\mathrm{P}$ nnm and P $21 / n$ and obtained nearly identical $R_{\text {Bragg }}$ factors $(=0.074)$ and goodness-of-fit values $(=2.30)$. During the course of sample identification for the RRUFF project, we discovered an untwined and phosphate-containing single-crystal of olivenite from Majuba Hill, Pershing County, Nevada, USA, and conducted a detailed structure refinement.

This paper reports the crystal structure dicuivre (II) monophosphate hydroxide $\mathrm{Cu}_{2}\left(\mathrm{PO}_{4}\right)(\mathrm{OH})$. This has been synthesized hydrothermally at $453 \mathrm{~K}$ for 72 hours.

\section{Experiment}

The single crystal of $\mathrm{Cu}_{2}\left(\mathrm{PO}_{4}\right)(\mathrm{OH})$ is prepared hydrothermally from acidic phosphoric.

The reaction mixture was homogenized in $5 \mathrm{ml}$ water.

The crystal structure has been refined in the space group $\mathrm{P} n \mathrm{n} \mathrm{m}$ and the lattice parameters $a=8.07$ (1) $\AA$; $b=8.37$ (1) $\AA$; c =5.859 (10) $\AA$.

In case of the Kappa CCD- based measurements, the corresponding software was Denzo-SMN (processing) [12] and HKL-SCALEPACK (multi-scan absorption correction) [13], respectively. All crystal structure were solved using direct methods and were subsequently refined with full matrix least squares refinements on $\mathrm{F}^{2}$ with the SHELXTL software suite [14]. In the final refinement cycles the displacement parameters of all atoms were refined anisotropically.

The Fourier transform infrared (FT-IR) measurements were performed at room temperature. On a JASCO FT-IR 420 spectrometer over the $4000-400 \mathrm{~cm}^{-1}$ region, in a $\mathrm{KBr}$ pellet. Furthermore, Raman spectra were measured with a LABRAMHR 800 triple monochromatic at room temperature under a $50 \times$ LF objective microscope, a He-Ne ion laser operating at about $300 \mathrm{~mW}$ was used (on the triple) as an excitation source $(514.532 \mathrm{~nm})$, with a spectral steps of $3 \mathrm{~cm}^{-1}$.

\section{Results and discussion}

\subsection{Refinement of the structure}

The refinement was achieved on the basis of 2090 independent reflections with $I>2 \sigma(I)$. Atomic positions of $\mathrm{Cu}_{2}$ ) and $\mathrm{P}$ were determined using the heavy atom method.

$\left(\mathrm{Cu}_{1}\right.$,

Fourier difference allows oxygen ions to be localized. In addition, the Fourier map has clearly shown that tow cuivre positions.

Detailed conditions of collection and structure refinement are summarized in table. 1.

Selected bond lengths, angles, the atomic positions and Thermal anisotropic are reported in tables 2, 3 and 4 respectively.

The structure of $\mathrm{Cu}_{2}\left(\mathrm{PO}_{4}\right)(\mathrm{OH})$ consists of chains of edge-sharing $\left[\mathrm{Cu}_{2} \mathrm{O}_{4}(\mathrm{OH})_{2}\right]$ octahedra extending parallel to [001] that are cross-linked by sharing corners with isotated $\mathrm{PO}_{4}$ tetrahedra to form an open framework. Channels in the framework contain dimmers of edge-sharing $\left[\mathrm{Cu}_{1} \mathrm{O}_{4}(\mathrm{OH})\right]$ trigonal bipyramids that share corners with the $\left[\mathrm{Cu}_{2} \mathrm{O}_{4}(\mathrm{OH})_{2}\right]$ octahedral and $\mathrm{PO}_{4}$ tetrahedra (Fig. 1.) Although the average $\left\langle\mathrm{P}_{1}-\mathrm{O}\right\rangle,\left\langle\mathrm{Cu}_{1}-\mathrm{O}\right\rangle$ and $\left\langle\mathrm{Cu}_{2}-\mathrm{O}\right\rangle$ distances of our study agree well with those given by Toman [10] and Burns and Hawthorne[11], the corresponding individual bond distances and angles from the three structure refinements (including ours) vary significantly. For example, the shortest and longest $\mathrm{P}-\mathrm{O}$ bond distances within the $\mathrm{PO}_{4}$ tetrahedra are $1.618 \mathrm{~A}^{\circ}\left(\mathrm{As}-\mathrm{O}_{5}\right)$ and $1.731 \mathrm{~A}^{\circ}\left(\mathrm{As}-\mathrm{O}_{4}\right)$, respectively, from Toman [10], $1.640 \mathrm{~A}^{\circ}$ (As $\left.-\mathrm{O}_{4}\right)$ and $1.702 \mathrm{~A}^{\circ}\left(\mathrm{As}-\mathrm{O}_{1}\right)$ from [11], and 1.520(2) $\mathrm{A}^{\circ}\left(\mathrm{P}-\mathrm{O}_{4}\right)$ and 1.562(3) $\mathrm{A}^{\circ}\left(\mathrm{P}_{-} \mathrm{O}_{1}\right)$ from this study. The shortest $\mathrm{Cu}-$ $\mathrm{O}$ bond length within the $\left[\mathrm{Cu}_{1} \mathrm{O}_{4}(\mathrm{OH})\right]$ trigonal bipyramid is $1.928(3) \mathrm{A}^{\circ}\left(\mathrm{Cu}_{1}-\mathrm{O}_{3}\right)$ from this study, but is $1.917 \mathrm{~A}^{\circ}\left(\mathrm{Cu}_{1}-\mathrm{O}_{3}\right)$ from [10] and $1.938 \mathrm{~A}^{\circ}$ from [11]. 
The structure consiste of infinite $\mathrm{Cu}-\mathrm{O}$ edge-sharing octahedral chains runing parallel to the $\mathrm{c}$ axis. Cu-O trigonal bipyramids alternating with tetrahedral from ladders with the edge sharing trigonal bipyramids as rungs. The ladders run parallel to the $\mathrm{c}$ axis and link to the octahedral chains by corner sharing to from a three dimensional structure with strong chain character. Relationship with sarkinite. Sarkinite is the dimorph of eveite and structure cell data suggest that it belongs to the wagnerite, $\mathrm{Mg}_{2}\left(\mathrm{PO}_{4}\right) \mathrm{F}$ structure type. As shown in fig. 2 the cation $\mathrm{Cu}(1)$ is coordinated to five oxygen anions. Each polyhedron is linked to four $\mathrm{PO}_{4}$ tetrahedrons via corners and two other tetrahedrons via edges. Fig. 3 presents the $\mathrm{Cu}(2)$ cation is inserted into six fold sites. Each polyhedron is linked to three $\mathrm{PO}_{4}$ tetrahedrons via corners.

The $\mathrm{H}$ atoms is bonded to $\mathrm{O}_{3}$, at a separation of 0.899 (9) $\mathrm{A}^{\circ}$. This distance is in fairly agreement with that $\left(0.77 \mathrm{~A}^{\circ}\right)$ reported for adamite [16].

Table. 1. Procedures for data collection and refinement of $\mathrm{Cu}_{2}\left(\mathrm{PO}_{4}\right)(\mathrm{OH})$.

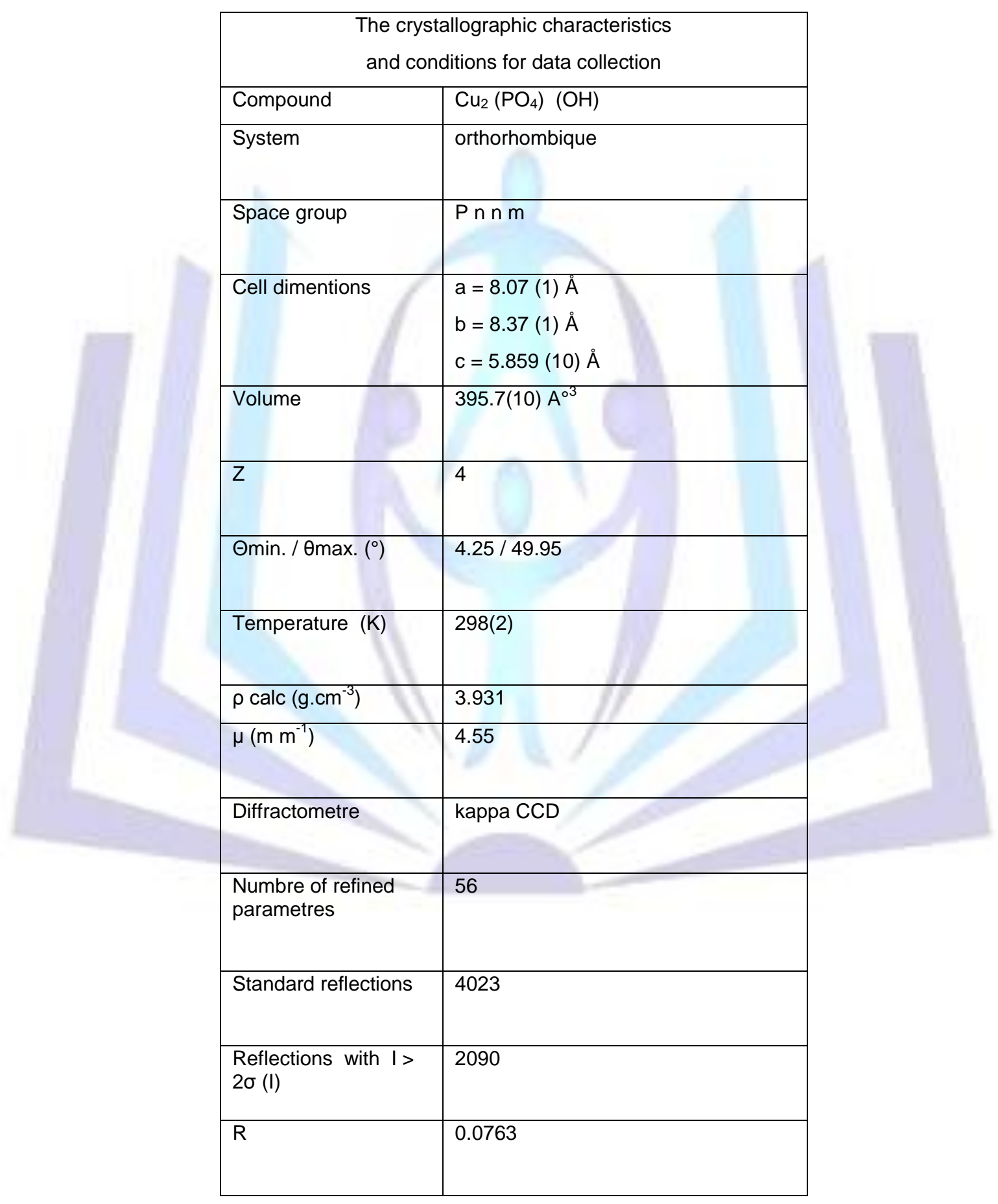


Table. 2. Main interatomic distances and bond angles obtained for $\mathrm{Cu}_{2}\left(\mathrm{PO}_{4}\right)(\mathrm{OH})$.

\begin{tabular}{|l|l|}
\hline Atoms & Distances $(\AA)$ \\
\hline $\mathrm{Cu}_{1}-\mathrm{O}_{3}$ & $1.928(3)$ \\
\hline $\mathrm{Cu}_{1}-\mathrm{O}_{2}{ }^{\prime}$ & $1.944(3)$ \\
\hline $\mathrm{Cu}_{1}-\mathrm{O}_{4}{ }^{\text {II }}$ & $2.047(3)$ \\
\hline $\mathrm{Cu}_{1}-\mathrm{O}_{4}{ }^{\text {III }}$ & $2.048(2)$ \\
\hline $\mathrm{Cu}_{1}-\mathrm{O}_{4}$ & $2.048(2)$ \\
\hline $\mathrm{Cu}_{2}-\mathrm{O}_{1}{ }^{\mathrm{IV}}$ & $1.9642(19)$ \\
\hline $\mathrm{Cu}_{2}-\mathrm{O}_{1}$ & $1.9642(19)$ \\
\hline $\mathrm{Cu}_{2}-\mathrm{O}_{3}{ }^{\mathrm{v}}$ & $1.922(2)$ \\
\hline $\mathrm{Cu}_{2}-\mathrm{O}_{3}$ & $1.977(2)$ \\
\hline $\mathrm{Cu}_{2}-\mathrm{O}_{4}{ }^{\mathrm{VI}}$ & $2.376(2)$ \\
\hline $\mathrm{Cu}_{2}-\mathrm{O}_{4}{ }^{\mathrm{vII}}$ & $2.376(2)$ \\
\hline $\mathrm{P}-\mathrm{O}_{4}{ }^{\mathrm{VIII}}$ & $1.520(2)^{\star} 2$ \\
\hline $\mathrm{P}-\mathrm{O}_{2}$ & $1.545(3)$ \\
\hline $\mathrm{P}-\mathrm{O}_{1}$ & $1.562(3)$ \\
\hline
\end{tabular}

\begin{tabular}{|c|c|}
\hline Atoms & Angles $\left({ }^{\circ}\right)$ \\
\hline $\mathrm{O}_{3}-\mathrm{Cu}_{1}-\mathrm{O}_{2}{ }^{1}$ & 176. 16(13) \\
\hline $\mathrm{O}_{3}-\mathrm{Cu}_{1}-\mathrm{O}_{4}{ }^{\mathrm{III}}$ & $88.51(8)$ \\
\hline $\mathrm{O}_{2}^{\prime}-\mathrm{Cu}_{1}-\mathrm{O}_{4}{ }^{\prime \prime \prime}$ & $95.89(9)$ \\
\hline $\mathrm{O}_{2}^{\prime}-\mathrm{Cu}_{1}-\mathrm{O}_{4}{ }^{\prime \prime \prime}$ & $95.89(9)$ \\
\hline $\mathrm{O}_{2}^{\prime \prime}-\mathrm{Cu}_{1}-\mathrm{O}_{4}{ }^{\prime \prime \prime I}$ & $124.36(8)$ \\
\hline $\mathrm{O}_{4}{ }^{\prime \prime \prime}-\mathrm{Cu}_{1}-\mathrm{O}_{4}$ & 111. 28(15) \\
\hline $\mathrm{O}_{4 \mathrm{vi}}-\mathrm{Cu}_{2}-\mathrm{O}_{2}{ }^{\prime \prime}$ & $92.51(12)$ \\
\hline $\mathrm{O}_{3}-\mathrm{Cu}_{2}-\mathrm{O}_{3}$ & $95.13(10)$ \\
\hline $\mathrm{O}_{1}{ }^{\mathrm{IV}}-\mathrm{Cu}_{2}-\mathrm{O}_{1}$ & 83. 85(12) \\
\hline $\mathrm{O}_{1}{ }^{\mathrm{IV}}-\mathrm{Cu} 2-\mathrm{O}_{3}^{\mathrm{v}}$ & $96.20(9)$ \\
\hline $\mathrm{O} 1^{\mathrm{IV}}-\mathrm{Cu}_{2}-\mathrm{O}_{3}$ & $175.63(11)$ \\
\hline $\mathrm{O}_{1}-\mathrm{Cu}_{2}-\mathrm{O}_{3}$ & $96.20(9)$ \\
\hline $\mathrm{O}_{3}{ }^{\mathrm{v}}-\mathrm{Cu}_{2}-\mathrm{O}_{3}$ & $84.08(12)$ \\
\hline $\mathrm{O}_{1}{ }^{\mathrm{IV}}-\mathrm{Cu}_{2}-\mathrm{O}_{4}{ }^{\mathrm{vl}}$ & $93.08(10)$ \\
\hline $\mathrm{O}_{3}-\mathrm{Cu}_{2}-\mathrm{O}_{4}{ }^{\mathrm{VII}}$ & $91.27(10)$ \\
\hline $\mathrm{O}_{3}{ }^{\mathrm{v}}-\mathrm{Cu}_{2}-\mathrm{O}_{4}{ }^{\mathrm{vI}}$ & $80.48(10)$ \\
\hline $\mathrm{O}_{3}-\mathrm{Cu}_{2}-\mathrm{O}_{4}{ }^{\mathrm{vII}}$ & $80.49(10)$ \\
\hline $\mathrm{O}_{4}{ }^{\mathrm{iv}}-\mathrm{Cu}_{2}-\mathrm{O}_{4}{ }^{\mathrm{vii}}$ & $168.94(10)$ \\
\hline $\mathrm{O}_{1}{ }^{\mathrm{IV}}-\mathrm{Cu}_{2}-\mathrm{O}_{4}{ }^{\mathrm{VII}}$ & $95.15(11)$ \\
\hline
\end{tabular}




\begin{tabular}{|l|l|}
\hline $\mathrm{O}_{1}-\mathrm{Cu}_{2}-\mathrm{O}_{4}{ }^{\mathrm{VII}}$ & $93.08(10)$ \\
\hline $\mathrm{O}_{3}{ }^{\mathrm{V}}-\mathrm{Cu}_{2}-\mathrm{O}_{4}{ }^{\mathrm{VII}}$ & $91.27(10)$ \\
\hline $\mathrm{O}_{4}{ }^{\mathrm{VIII}}-\mathrm{P}-\mathrm{O}_{4}$ & $109.3(2)$ \\
\hline $\mathrm{O}_{4}{ }^{\mathrm{VIII}}-\mathrm{P}-\mathrm{O}_{2}$ & $109.71(13)$ \\
\hline $\mathrm{O}_{4}{ }^{\mathrm{VII}}-\mathrm{P}-\mathrm{O}_{1}$ & $110.99(10)$ \\
\hline $\mathrm{O}_{4}-\mathrm{P}-\mathrm{O}_{1}$ & $110.99(10)$ \\
\hline $\mathrm{O}_{2}-\mathrm{P}^{-} \mathrm{O}_{1}$ & $106.16(17)$ \\
\hline $\mathrm{P}-\mathrm{O}_{4}-\mathrm{Cu}_{1}$ & $132.63(13)$ \\
\hline $\mathrm{P}-\mathrm{O}_{4}-\mathrm{Cu}_{2}{ }^{\prime}$ & $116.78(11)$ \\
\hline $\mathrm{Cu}_{1}-\mathrm{O}_{4}-\mathrm{Cu}_{2}{ }^{\prime}$ & $110.17(9)$ \\
\hline
\end{tabular}

Symmetry codes :

(i) $x-1 / 2,-y+1 / 2,-z+1 / 2$

(ii) $\quad x-1 / 2,-y+1 / 2,-z+1 / 2$
(iii)
$x, y,-z$

(iv) $-x+2,-y,-z+1$

(v) $\quad-x+2,-y,-z$

(vi) $\quad-x+3 / 2, y-1 / 2,-z+1 / 2$

(vii) $\quad x+1 / 2,-y+1 / 2,-z+1 / 2$

(viii) $\quad x, y,-z+1$

(ix) $\quad-x+3 / 2, y+1 / 2, z+1 / 2$

Table. 3. Atomic coordinates for $\mathrm{Cu}_{2}\left(\mathrm{PO}_{4}\right)(\mathrm{OH})$.

\begin{tabular}{|l|l|l|l|l|}
\hline & $\mathrm{X}$ & $\mathrm{Y}$ & $\mathrm{Z}$ & Uiso*/ Ueq \\
\hline $\mathrm{P}$ & $0.76665(11)$ & $0.24873(10)$ & 0.5000 & $0.00124(14)$ \\
\hline O1 & $0.8657(3)$ & $0.0884(3)$ & 0.5000 & $0.0030(3)$ \\
\hline O2 & $0.8974(4)$ & $0.3836(4)$ & 0.5000 & $0.0123(6)$ \\
\hline O3 & $0.8759(3)$ & $0.1034(3)$ & 0.0000 & $0.0022(3)$ \\
\hline O4 & $0.6586(3)$ & $0.2624(3)$ & $0.2885(3)$ & $0.0081(3)$ \\
\hline Cu1 & $0.63815(5)$ & $0.12570(6)$ & 0.000 & $0.00506(11)$ \\
\hline Cu2 & 1.00000 & 0.00000 & $0.25058(7)$ & $0.00449(12)$ \\
\hline H & $1.022(15)$ & $0.058(14)$ & 0.500 & $0.02(3)^{*}$ \\
\hline
\end{tabular}


Table. 4. Thermal anisotropic of $\mathrm{Cu}_{2}\left(\mathrm{PO}_{4}\right)(\mathrm{OH})$.

\begin{tabular}{|l|l|l|l|l|l|l|}
\hline & $U^{11}$ & $U^{22}$ & $U^{33}$ & $U^{12}$ & $U^{13}$ & $U^{23}$ \\
\hline P & $0.000(3)$ & $0.0037(3)$ & $0.000(3)$ & $0.00087(19)$ & 0.000 & 0.000 \\
\hline O1 & $0.0039(8)$ & $0.0051(7)$ & $0.000(6)$ & $0.0039(6)$ & 0.000 & 0.000 \\
\hline O2 & 0.000 & $0.0062(9)$ & $0.031(2)$ & $-0.0005(6)$ & 0.000 & 0.000 \\
\hline O3 & $0.0002(6)$ & $0.0063(7)$ & $0.000(6)$ & $-0.0001(5)$ & 0.000 & 0.000 \\
\hline O4 & $0.0107(7)$ & $0.0137(7)$ & $0.0000(5)$ & $0.0084(6)$ & $-0.0057(5)$ & $-0.0039(5)$ \\
\hline Cu1 & $0.00001(16)$ & $0.00818(18)$ & $0.00700(19)$ & $0.00049(10)$ & 0.000 & 0.000 \\
\hline Cu2 & & & & & & 0.000 \\
\hline
\end{tabular}

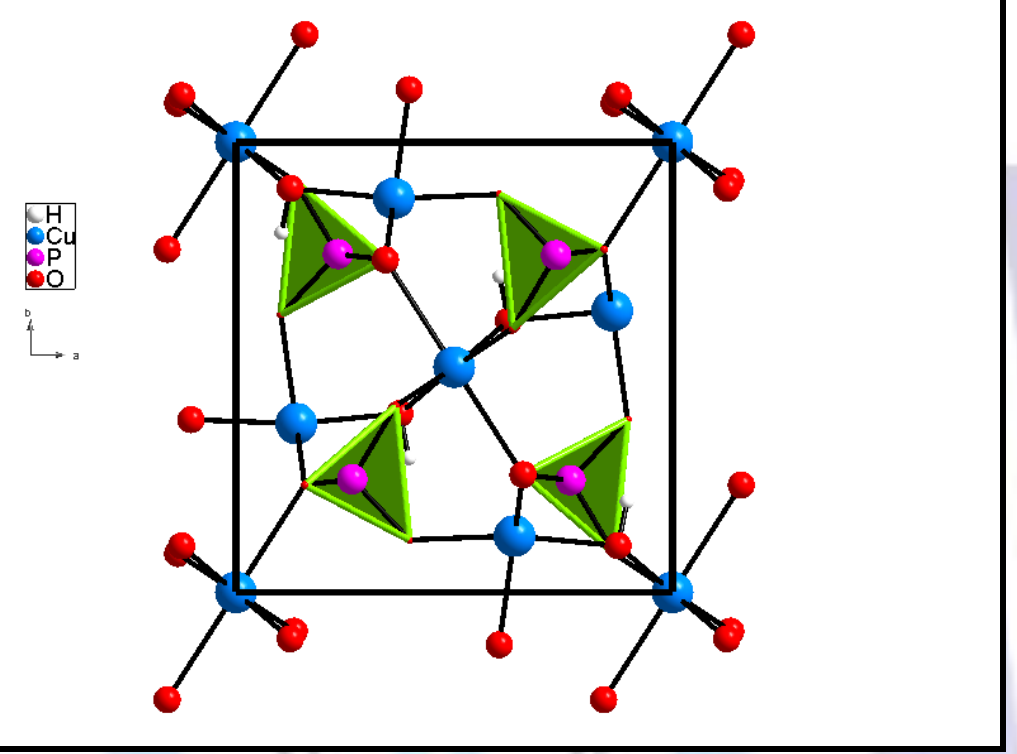

Figure. 1. Projection of $\mathrm{Cu}_{2}\left(\mathrm{PO}_{4}\right)(\mathrm{OH})$.

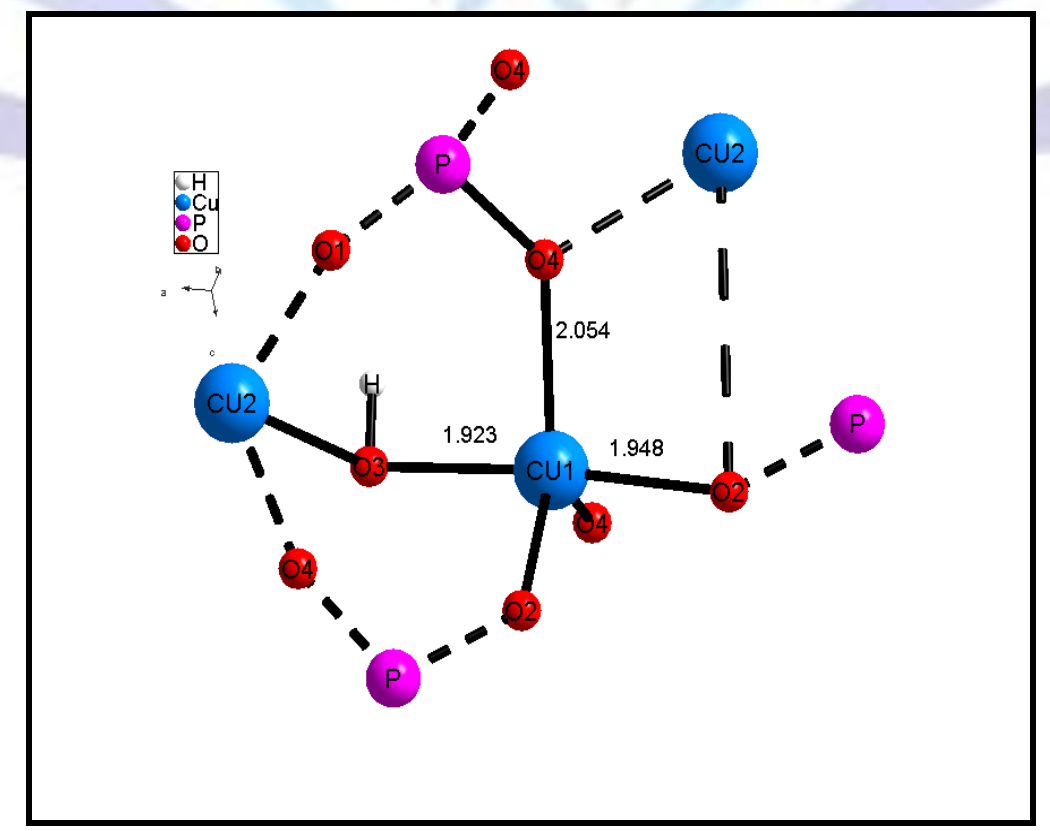




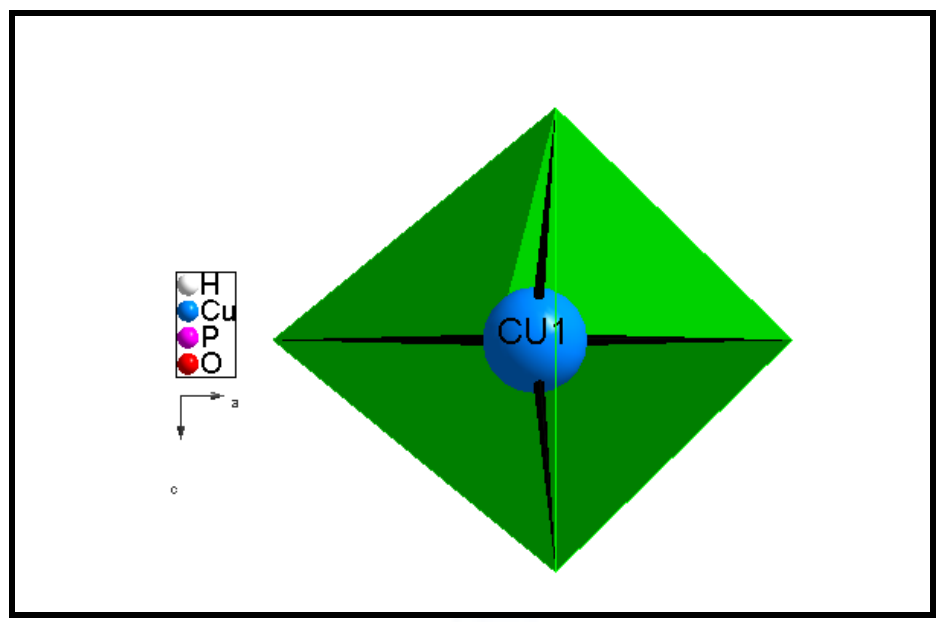

Figure. 2. Coordination of the metal $\mathrm{Cu}$ (1).

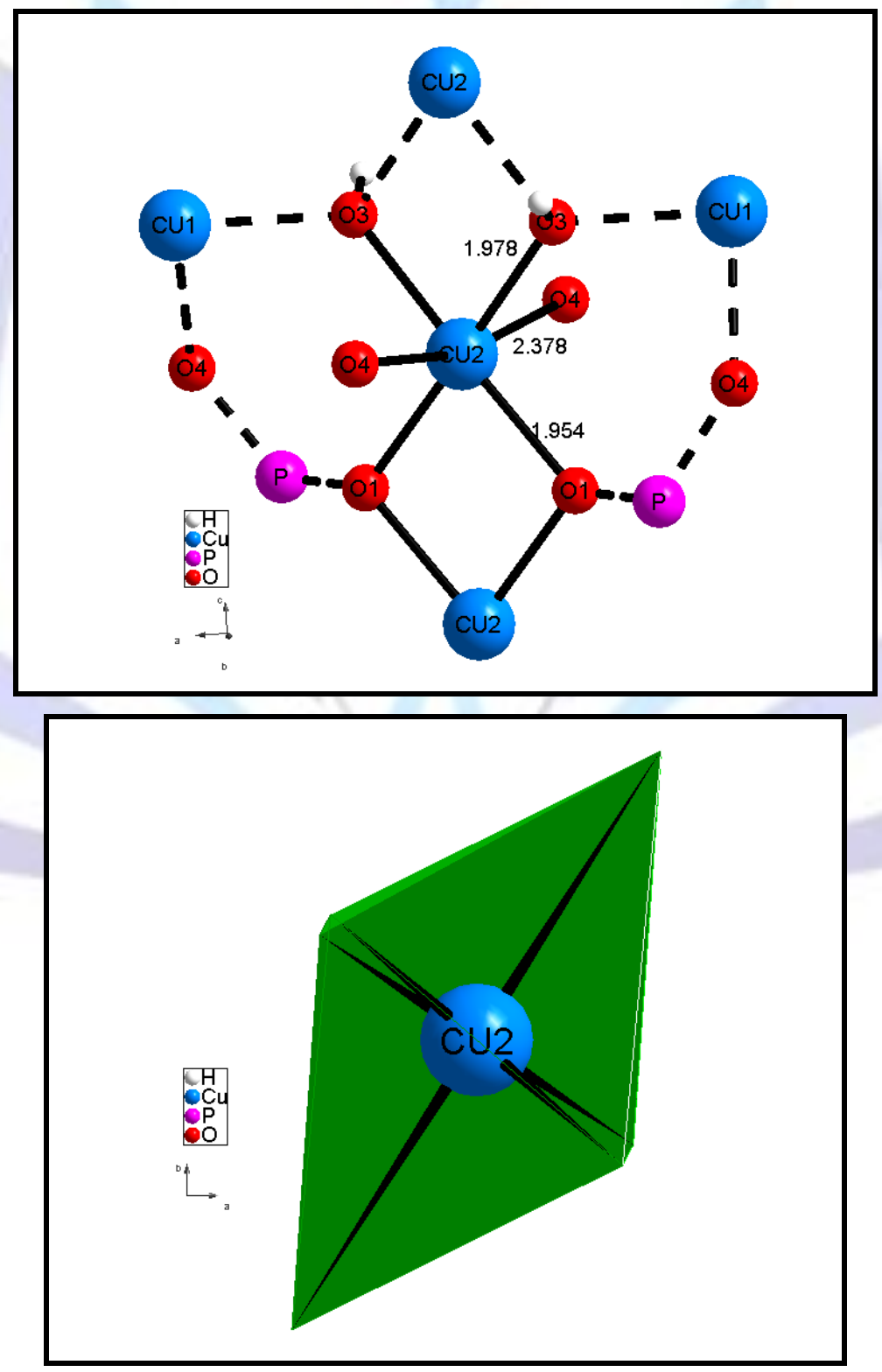

Figure. 3. Coordination of the metal $\mathrm{Cu}$ (2). 


\section{Spectroscopy analysis}

FT-IR is one of the most general spectroscopic techniques used to identify the functional groups in materials. It is an important and popular tool for structural exposition and compound identification. The infrared spectra of the compounds obtained from the thermal vibration of $\mathrm{Cu}_{2}\left(\mathrm{PO}_{4}\right)(\mathrm{OH})$ is show in fig. 4. The presence of a sharp vibrational band at approximated $3535 \mathrm{~cm}^{-1}$ for $\mathrm{Cu}_{2}\left(\mathrm{PO}_{4}\right)(\mathrm{OH})$ is attributed to the stretching mode of the $\mathrm{O}-\mathrm{H}$ band.

The band observed between $936 \mathrm{~cm}^{-1} v_{1}$ and $650 \mathrm{~cm}^{-1} v_{4}$ are attributed to the stretching vibration mode of the $\left(P O_{4}\right)^{3-}$ groups the position of these bands were similar to those $\left(950\right.$ and $\left.700 \mathrm{~cm}^{-1}\right)$ previously reported by I. De Pedro and all [15].

The $v_{\text {as }}$ asymmetrical stretching mode $v_{\text {as }}(\mathrm{P}-\mathrm{O})$ appareas at frequencies 881,837 and $812 \mathrm{~cm}^{-1}$ for $\mathrm{Cu}_{2}(\mathrm{PO})(\mathrm{OH})$.

The peak observed at $605 \mathrm{~cm}^{-1}$ characteristic of the symmetric $v_{\mathrm{s}}(\mathrm{P}-\mathrm{O})$ stretch. This band appears when $\mathrm{Cu}_{2}\left(\mathrm{PO}_{4}\right)(\mathrm{OH})$.

The single -crystal laser Raman spectra of both $\mathrm{Cu}_{2}\left(\mathrm{PO}_{4}\right)(\mathrm{OH})$ is given in Fig. 5. Two major bands in the hydroxyl stretching $\left(\mathrm{V}_{\mathrm{OH}}\right)$ region: one at $3445 \mathrm{~cm}^{-1}$ and the other at $3463 \mathrm{~cm}^{-1}$.

Similar wavenumbers $\left(\mathrm{V}_{\mathrm{OH}}=3437 \mathrm{~cm}^{-1}\right.$ and $\left.3464 \mathrm{~cm}^{-1}\right)$ were also obtained by Frost et al [17] Given the correlation between $\mathrm{VOH}_{\mathrm{OH}}$ and $\mathrm{O}-\mathrm{H}$...O distances in minerals (libowitzky) [18], one would expect two $\mathrm{O}-\mathrm{H}$...O distances between 2.8 and $2.9 \mathrm{~A}^{\circ}$ in olivenite. Our structural data indeed show that $\mathrm{O}_{3}(=\mathrm{OH})$ atom is at a distance of $2.79 \mathrm{~A}^{\circ}$ from $\mathrm{O}_{1}$ and 2.838 $A^{\circ}$ from $\mathrm{O}_{4}$. Nevertheless, the angles $\mathrm{O}_{3}-\mathrm{H}_{\ldots} . \mathrm{O}_{4}\left(110^{\circ}\right)$ and $\mathrm{O}_{3}-\mathrm{H} \ldots . \mathrm{O}_{1}\left(90^{\circ}\right)$ appear to be too small for hydrogen bonding. Note that, based on the structure refinement of liberthenite, the phosphate analogue of olivenite, Cordsen [19] proposed a bifurcated hydrogen bonding model for this mineral, in which thereare two $\mathrm{O}-\mathrm{H}$.... $\mathrm{O}$ bonds at the same distance of $2.84 \mathrm{~A}^{\circ}$ and two bonding angles of $110^{\circ}$. Raman spectra of the tetrahedral anions in aqueous systems are well known. The symmetric stretching vibration of the dicuivre (II) monophosphate hydroxide anions $\left(v_{1}\right)$ is observed at $954 \mathrm{~cm}^{-1}$ and coincides with the position of the asymmetric stretching mode $\left(v_{3}\right)$. The symmetric bending mode $\left(v_{2}\right)$ is observed at 407 $\mathrm{cm}^{-1}$ and the out-of-plane bending modes $\left(v_{4}\right)$ is observed at $501 \mathrm{~cm}^{-1}$. Of all the tetrahedral oxyanions spectra, the positions of phosphate vibrations occur at lower wavenumbers than any of the other naturally occurring mineral oxyanions spectra. The $v_{1}$ and $v_{3}$ bands of $\mathrm{Cu}_{2}\left(\mathrm{PO}_{4}\right)(\mathrm{OH})$ were observed at $890,813,887 \mathrm{~cm}^{-1}$ and 1322 and $2645 \mathrm{~cm}^{-1}$ respectively. The bending modes were found at $407 \mathrm{~cm}^{-1}$ and $413 \mathrm{~cm}^{-1}$.

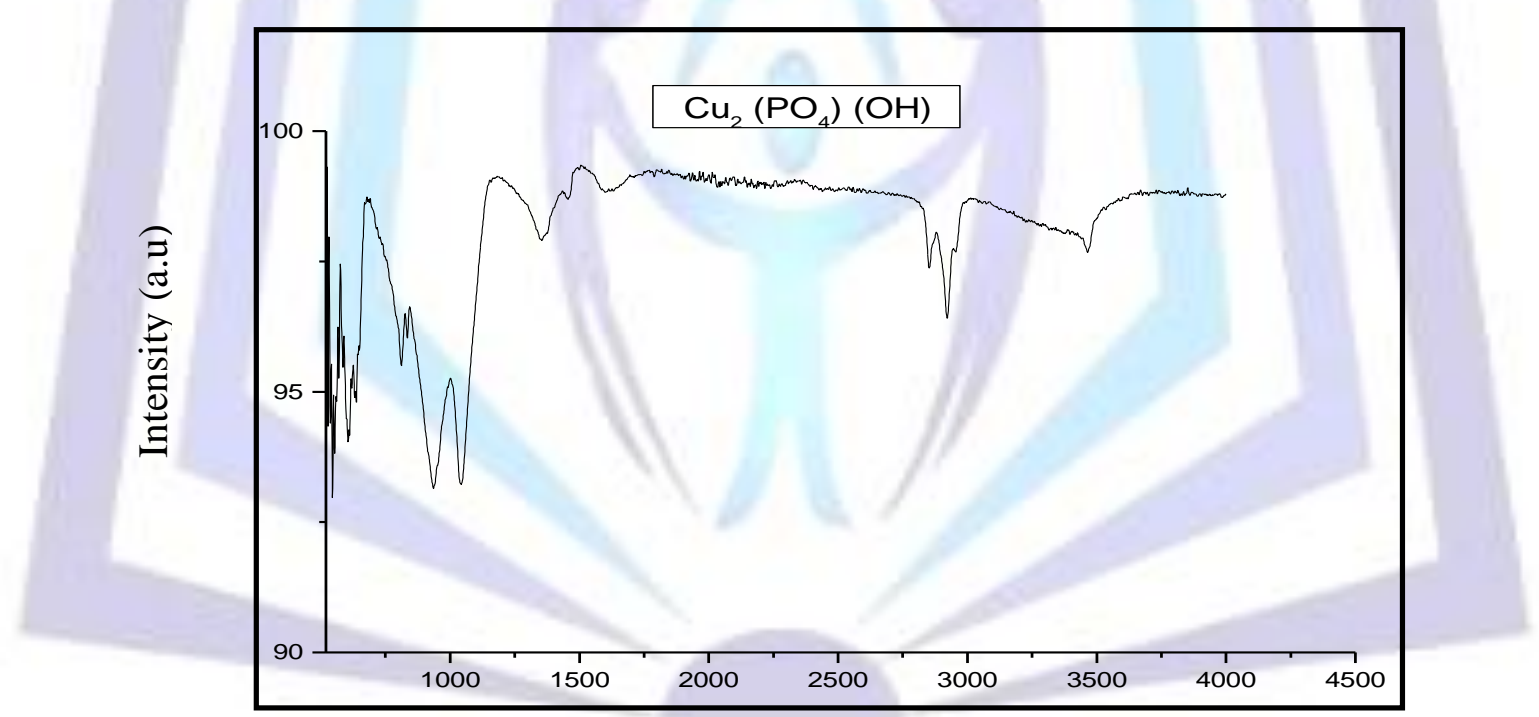

Wavenumber $\left(\mathrm{cm}^{-1}\right)$

Figure. 4. Infrared spectrum of $\mathrm{Cu}_{2}\left(\mathrm{PO}_{4}\right)(\mathrm{OH})$. 


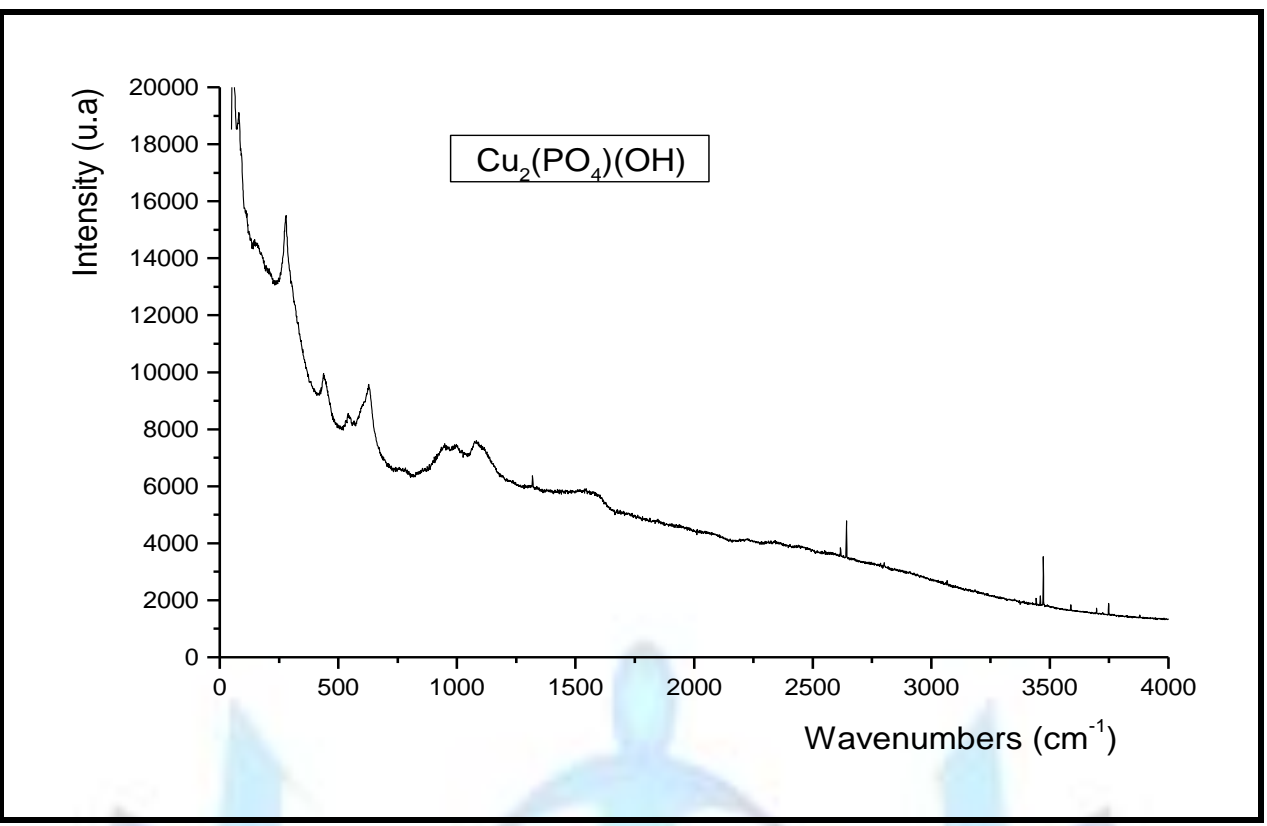

Figure. 5. Raman spectrum of $\mathrm{Cu}_{2}\left(\mathrm{PO}_{4}\right)(\mathrm{OH})$.

Table. 5. Spectral data and band assignments Raman and IR of Cu2 (PO4) (OH).

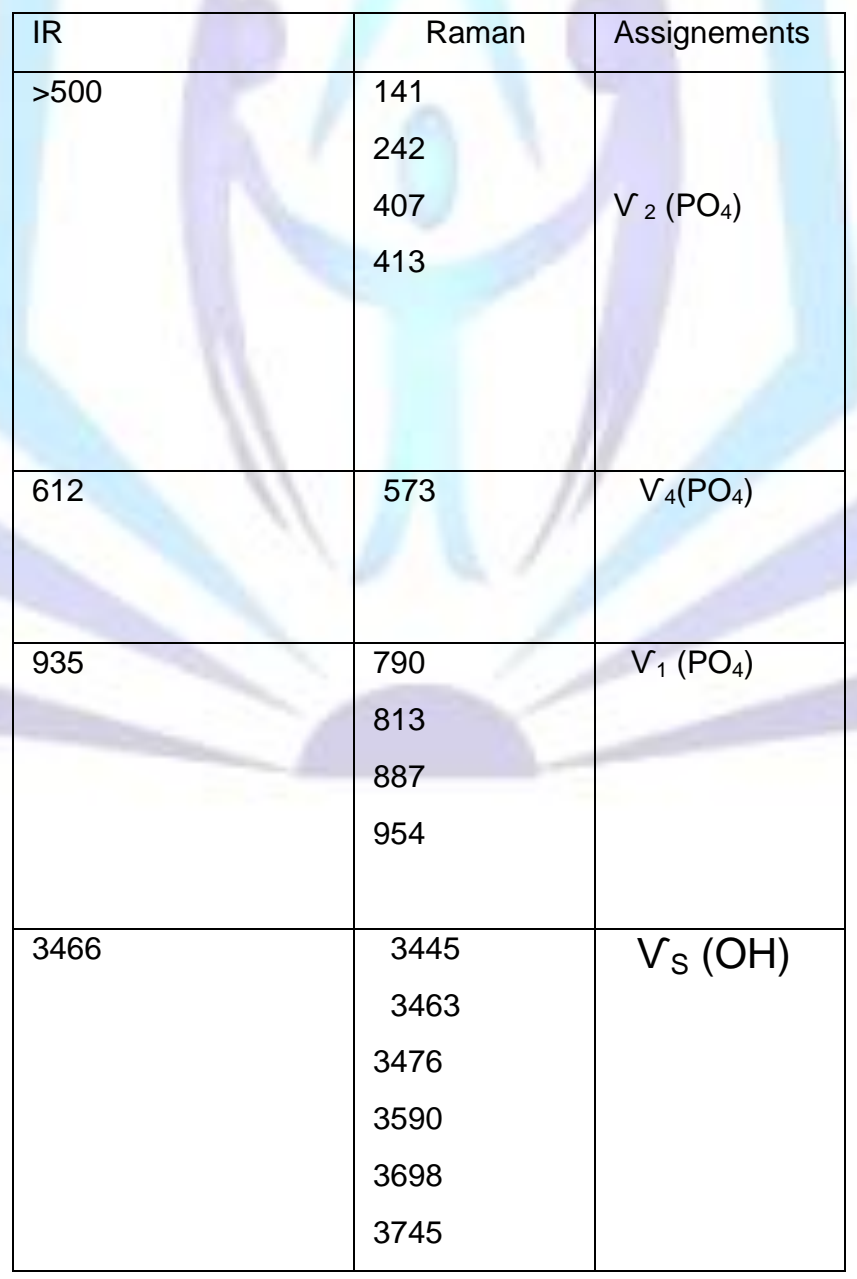




\section{Conclusion}

The results from X-ray diffraction $(\mathrm{XRD})$ as shown that formula was $\mathrm{Cu}_{2}\left(\mathrm{PO}_{4}\right)(\mathrm{OH})$. The analysis of data from vibrational spectroscopy has also provided support for the high symmetry $\mathrm{P} n \mathrm{n} \mathrm{m}$ space group.

\section{References:}

[1] Durif, A., Averduch-Pouchot, M. T.,Bull. Soc. Mineral crystallogr. 91 (1968) 495.

[2] Tranqui, D., Durif, A., Guitel, J-C. Averduch-Pouchot, M. T. Bull. Soc. Mineral. Crystallogr. 91 (1968) 10.

[3] Yakubovich, O.V. Karimava, O.V. Dimitrova, O. V. Massa, W. Actacrystallogr C55(1999) 151.

[4] Goni, A. Pzarro, J.L. Lezema, L.M. Barberis, G.E. Arriortua, M. I. Rojo, T. Mater, J.Chem.6 (1996) 421.

[5] lovanovski, G. Pocev, S. Kaitner, B. Bull. Chem. Technol. Macedonia 16 (1997) 59.

[6] Heritsch, H. Z. Acta crystallogr. 99 (1938) 466.

[7] Richmond, W.E. Am. Mineral. 25 (1940) 441.

[8] Berry, L. G. Am Mineral 36 (1951) 484.

[9] Walitzi, E. M. Tschermaks Mineral. Petrol. Mitt. 8 (1963) 275.

[10] Toman, K. Acta Crystallogr. B33 (1977) 2628.

[11] Burns, P. C. and Hawthorne, F. C. Can. Mineral. 33 (1995) 885.

[12] Ficsher, P. Waldner, F. Solid State Commun 44 (1982) 657.

[13] Radaev, S. F. Muradayn, L. A. Kargin, Yu. F. Sarlin, V. A. Kanepit, V. N. Simonov, V. I. Sov.Phy.Crystallogr. 35 (1990) 204.

[14] Barbier, J. Greedan, J. E. asaro, T. Mc Carthy, G. J, Eur. J. Solid State Inorg. Chem. 27 (1990) 204.

[15] De Pedro,I. Rojo, M. J. Insausti, M. Mesa, J. L. Arriortua, M. I and Rojo, T. Z. Anorg. Allg. Chem 631 (2005) 2096.

[16] Hill, R. J. Am. Mineral. 61 (1976) 979.

[17] Frost, R. L. Martens, W. N and Williams, P. A. J. Raman Spectrosc. 33 (2002) 475.

[18] Libowitzky, E. Monatsh. Chem.130 (1999) 1047.

[19] Cordsen, A. Can. Mineral. 16 (1978) 153. 